\title{
Correlation Between Students Creative Thinking Ability in Solving Environmental Problem with Achievement of Environmental Education
}

\author{
Meitiyani $^{1, a)}$, Mega Elvianasti ${ }^{1}$, Agus Pambudi Dharma ${ }^{1}$

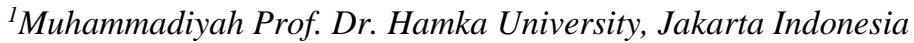 \\ a)Correspondent author: meitiyani@uhamka.ac.id
}

\begin{abstract}
Education has the opportunity to develop creative individuals who have ideas and solutions in responding challenges and providing solutions the problems in the 21 st century. The research conducted to measure the relationship between students' creative thinking skills in solving environmental problems with the achievement of the Environmental Education course. The study population included all students of the Uhamka Biology Education study program semesrer III 2019 and the sample of this study was 48 students. The instrument resesearch were essay questions and the value of Environmental Education course. Data correlation analysis used linear regression test using SPSS. The results showed the significance value of the linearity test was $0.831>0.05$, which indicated that there was a significant relationship between students' creative thinking skills in solving environmental problems with the environmental education course achievement. The result regression equation $\mathrm{Y}=62,139+0,310 \mathrm{X}$. Hypothesis testing results in $\mathrm{t}$ value $(6.187)>\mathrm{t}$ table $(2.021)$, which indicates that there is an effect of students' creative thinking ability in solving environmental problems on the achievement of Environmental Education subjects.Coeficient correlation 67,4 and R Square is 0.454 , which shows contribution of students' creative thinking skills in solving environmental problems on environmental education course achievement is $45,4 \%$.
\end{abstract}

Keywords: creative thinking, environmental problem solving, environmental education.

\section{INTRODUCTION}

The success of the young generation is determined by their ability to excel and their success in facing the challenges of the development of civilization, science and technology. Educational institutions play a role in fostering students to develop character and potential for achievement. University is an institution that prepares students to become members of society with academic and professional abilities in order to apply, develop and create science, technology and arts. Saleh [1] said that the learning process in higher education requires students to be active in learning activities using various media and facilities, such as library books, journals and research proceedings, and the internet to develop their mindset. One of the ways to measure the academic success of students in university is their achievement, which is shown in the form of a Grade Point Average (GPA). According to Muhibbin [2], the factors that affect student academic achievement are divided into three, namely internal factors, external factors, and learning approach factors.
The learning approach as external factor needed to develop the characters to face the development of science and technology in the 21 st century. One of the abilities that is encouraged to be developed is the ability to think creatively. It is hoped that the development of creative thinking skills can solve the problems in the community. Programs to increase students creativity in the school environment are increasingly being carried out and have become one of the goals of educational activities carried out in various countries, Heilmann \& Korte [3] and Newton $\&$ Beverton [4]. Creative potential is perceived as cognitive and personality characteristics, such as different thinking abilities, imagination, openness, curiosity, and independence, Karwowski et.al [5]. Wardani [6] argues that learning activities should prepare students who have the ability to solve problems, critically, and creatively, in conditions with national, regional, and global insights.

Research on the relationship between the ability to think creatively and critically with learning achievement has been conducted by Gunawan [7] with the result that there is a contribution of $20.13 \%$ of the ability to think creatively towards learning outcomes 
in Science Concept II Course at PGSD Study Program, IKIP PGRI Madiun. Another study from Silaban [8] states there are strength of positive correlations which is significant between mastery of physics concept with problems solving ability, creativity with problem-solving ability, and mastery of physics concepts and creativity simultaneously with problem-solving ability. Also another study from Fatmawati [9] stated that there is a correlation between creative thinking skills and learning outcomes. The contribution given by creative thinking skills to learning outcomes is $14.7 \%$.

The learning process in environmental education can increase environmental awareness in creative ways. The general objectives of environmental education according to UNESCO in the Tbilisi conference [10] are: (1) to help explain issues of concern and concern about the interrelationship between economy, social, politics and ecology in cities and in rural areas; (2) to provide opportunities for everyone to develop the knowledge, values, attitudes, commitments, and abilities needed to protect and improve the environment, and (3) to create new patterns of behavior in individuals, groups and society as a whole towards environment. The objectives to be achieved include the following aspects: (1) knowledge, (2) attitude, (3) caring. (4) skills, and (5) participation.

Environmental education-based courses can lead to creative thinking skills that teach students to solve environmental problems they are facing properly. The results of problem solving by students can be useful in individual life and in the interests of society.

\section{METHOD}

This research is an "ex post facto" using correlational descriptive method. This study aims to determine the relationship between students' creative thinking skills in solving environmental problems and the environmental education course achievement quantitatively. The correlation coefficient can measure the level of the relationship between the student's creative thinking ability variable in solving environmental problems $(\mathrm{X})$ as a predictor variable with the Environmental Education course achievement variable $(\mathrm{Y})$ as the criterium variable.

The population in this study were all third semester students of the Uhamka Biology Education study program who had graduated from the Environmental Education course, consist of two classes. The sampling technique used in this study was simple random sampling, where each student in the two classes had the same opportunity to be used as a research sample. The total sample of this study was 48 students from a population of 71 students.

The data collection technique used in this study was a technical test in the form of questions to measure students' knowledge and ability to think creatively. The tests used in measuring the ability to think creatively in this study include aspects of creative thinking, namely fluency, flexibility, originality, and elaboration. The test materials used to measure the ability to think creatively are test questions that require students to be able to find problems solutions and dare to express opinions or ideas from case study questions about environmental problems around campus and student residences. There are 9 questions in essay form. While the academic achievement of the Environmental Education course is obtained from the academic score of students in that subject. The scoring of the creative thinking instrument uses an answer rubric based on creative thinking indicators with a range of 1 to 4 . The score obtained from each indicator is calculated and converted into a percentage as the final score of the students. Based on the calculation of Purwanto [11] this calculation is also called percentages correction, with the formula:

$$
\mathrm{NP}=\frac{\mathrm{R} \times 100 \%}{\mathrm{SM}}
$$

Description:

$$
\begin{aligned}
& \mathrm{NP} \quad \text { : The percent value sought or expected } \\
& \mathrm{R} \quad \text { : The raw score obtained bystudents } \\
& \mathrm{SM}: \text { The ideal maximum score from the test } \\
& \text { concerned }
\end{aligned}
$$$$
100 \text { : Fixed number }
$$

The data analysis used in this study is linear regression analysis to find the coefficient of the relationship between the independent variable $(\mathrm{X})$ the ability to think creatively in solving environmental problems with the dependent variable, namely the academic achievement of the Environmental Education subject $(\mathrm{Y})$, through the Hadi regression equation [12]:

$$
\mathrm{Y}=\mathrm{aX}+\mathrm{K}
$$

$\mathrm{Y}=$ criterion variable

$\mathrm{K}=$ constant number

$\mathrm{a}=$ regression coefficient

$\mathrm{X}=$ predictor variable

The regression analysis in this study used the SPSS.20 Statistic program. The regression coefficient obtained from the calculation results illustrates the amount of academic achievement in the environmental education course obtained at each $1 \%$ addition of the ability to think creatively about solving environmental problems. Furthermore, testing the hypothesis to ensure the significance of the regression coefficient.

\section{RESULTS AND DISCUSSION}

The results are a description of the data analysis variable $\mathrm{X}$ (the ability to think creatively about solving environmental problems and $\mathrm{Y}$ (achievement 
on a course for environmental education) that uses the correlation of linear regression.

\subsection{The ability of Creative Thinking on Solving Environmental Problems}

Based on the test results the ability to think creatively about solving environmental problems for class A and B semester III students of the Uhamka Biology education study program, the value distribution is obtained in (graph 1):

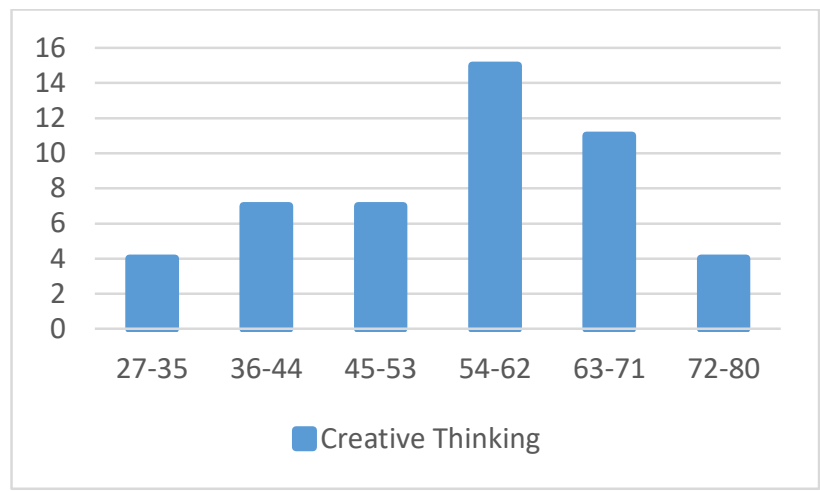

Graph 1: The distribution of values for the ability to think creatively about solving environmental problems.

The graph above shows that the highest values are in the range of 54-62 and the lowest values are in the range of $27-35$ and $72-80$. The average creative thinking ability of students in solving problems is $56 \%$ included in the medium category, with details in (table 1).

Table 1.Creative Thinking Ability Category

\begin{tabular}{crl}
\hline Number of Students & Percentage & Category \\
\hline 4 & $8.3 \%$ & Low \\
38 & $79.2 \%$ & Medium \\
6 & $12,5 \%$ & High \\
\hline Average & $56 \%$ & Moderate.
\end{tabular}

Data from the results of this study indicate that students' ability in creative thinking is mostly at the moderate level. Everyone has various life experiences which affect his level of creative thinking ability. The ability to think creatively in several studies in Indonesia is at a moderate level. The distribution of students' creative thinking abilities includes fluency $62 \%$ with the moderate category, flexibility $51 \%$ with moderate category, originality $49 \%$ in moderate category, and elaboration $27 \%$ with the low category. The aspect of fluency (fluency) measures the ability of students to make ideas smoothly. This aspect of fluency is the ability to generate lots of ideas smoothly and relevant to the problem, Munandar [13]. In this aspect, the issues raised to be handled creatively are assessing the students ideas in overcoming the problem of reducing plastic waste on campus and the idea of conducting socialization about the dangers of sterofoam as a solution to the problem of reducing sterofoam waste in the campus environment. An effective teaching and learning process occurs when students are actively involved in making perceptions of problems. So by developing creativity in students will encourage the ability to find and develop their own facts and concepts, as well as problem solving, Silaban [14]. The ability to think flexibly according to Munandar [13] is the ability to make changes to various approaches and directions of thought. The issue raised in this aspect is assessing the ability of students to develop ideas in designing anti-sterofoam campaigns and managing waste banks in overcoming the problem of the large amount of plastic waste, sterofoam in campus area. Based on the analysis of students' answers, some of the ideas that have emerged have different ways and different approaches.. Original thinking aspect is the ability to generate ideas which are new ideas. The problem raised measures the ability of students to come up with ideas to solve the problem of domestic waste in the environment where students 
live. New ideas are expected to emerge based on information and experience obtained from within the campus environment. The ability to think original according to Amtiningsih et al. [15] requires support for the ability of the smooth aspect (fluency) and flexibility which were developed before. Aspect of elaboration aspec means thinking in detail. Munandar [13] said is a skill in developing and enriching and expanding an idea in detail. The problems raised in this aspect require students to elaborate on ideas in recycling the problem of organic leaf waste in the campus yard. Analysis of the answers found generally did not describe the management process in detail, and rarely provided ideas that involved students and campus residents in sustainable waste management. Many of the ideas put forward by students in solving problems are still normative, some of the ideas appear in their own ways and flow interesting original ideas. According to Semiawan [16] creativity is a process of thinking about various ideas when dealing with problems. The process that is passed in expressing ideas is a challenge which is a fun thing in itself, by finding new relationships.

\subsection{Achievement of Environmental Education Subjects}

Based on the results of the Environmental Education Subject Achievement test for class A and B semester III students of the Uhamka Biology education study program, obtained by the distribution of values in (graph 2):

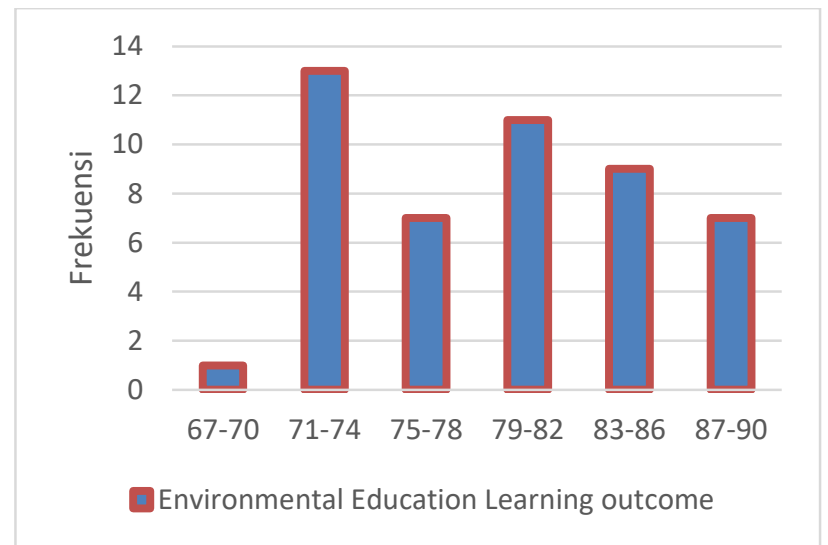

Graph 2. Distribution of Environmental Education course achievement

The graph above shows that the highest score is in the range of 71-74 and the lowest is in the range of 60-67.
The average environmental education achievement is 79 in the good category, with the details in (table 2):

Table 2.Achievement Categories for Environmental Education Subject

\begin{tabular}{ccc}
\hline Number of Students & Percentage & Categories \\
\hline 22 & $46 \%$ & good \\
26 & $54 \%$ & very good \\
\hline Average score & 79 & good \\
\hline
\end{tabular}

Environmental education programs of formal education are directed at achieving mastery of cognitive, affective and psychomotor aspects with the aim of changing behavior to play an active role in efforts to save the environment for the benefit of the current generation and next generation. The success of the awareness process and changing views of the environment in the Environmental Education course is largely determined by the ability of the lecturers to carry out the learning process. Environmental education is not an independent subject, however it is integrated into subjects of study in schools. The knowledge aspect helps students gain a basic understanding of the functions and problems of the environment, human interaction with the environment. Student learning achievement in this environmental education subject is achieved through a cognitive process which includes several aspects. Anderson et al [17] explained that student learning achievement can be reflected in the dimensions of student cognitive processes. This cognitive process dimension includes six levels of Bloom's Taxonomy that have been revised, namely: remembering, understanding, applying, analyzing, evaluating, and creating. Environmental education materials can include knowledge of environmental issues such as global 
warming, issues of pollution and environmental damage, energy, and waste management. Knowledge of environmental problems should given through the process of providing real experiences, especially about the actions students in preventing and overcoming environmental problems. Provides a holistic experience where students investigate real-world environmental problems through a multidisciplinary approach that leads them to identify and consider appropriate actions, Hungerford, Volk, et al. [18]. The cognitive processes measured in this study predominantly measure the ability to apply, analyze, evaluate, and create in overcoming solid waste pollution problems. The student's ability is classified as good in answering the problem of solid waste around campus. A small proportion of students get low scores because they still rely on their ability to remember and understand in answering questions.

\subsection{Relationship of students 'creative thinking abilities in solving environmental problems. Achievement of Environmental Education Subjects}

Based on the significance value of linearity, the value of linearity is 0.831 which is greater than the significance of 0.05 , which shows that there is a linear relationship between students' creative thinking abilities in solving environmental problems and the achievement of Environmental Education courses. Hypothesis testing uses product moment correlation analysis by Person. The results of the analysis show that the correlation between the creative thinking ability of students in solving environmental problems with the achievement of Environmental Education courses is 0.674 which indicates a strong relationship between students' creative thinking abilities in solving environmental problems and the achievement of Environmental Education courses. In line with Fatmawati's research [9], there is a correlation between creative thinking skills and learning outcomes. The amount of the contribution given by creative thinking skills to learning outcomes is $14.7 \%$. Regression analysis using the SPSS 2.0 Statistic program to find the regression equation. Based on the results of the analysis in the Coefficients table, the constant value is 62.139 and the regression coefficient is 0.310 , so that the regression equation is $\mathrm{Y}=62.139$ $+0.310 \mathrm{X}$. The constant is 62.139 , which indicates that if there is no increase in the score of students 'creative thinking ability in solving environmental problems, the learning achievement score for environmental education is 62,139 . There is a positive and linear relationship between the variables of students' creative thinking abilities in solving environmental problems with The achievement variable of Environmental Education subject is shown in (graph 3).

Furthermore, calculating the coefficient of determination (R2) with a result of 0.454 which shows that $45.4 \%$ of the academic achievement value of environmental education courses can be explained by variations in students' creative thinking abilities in solving environmental problems.

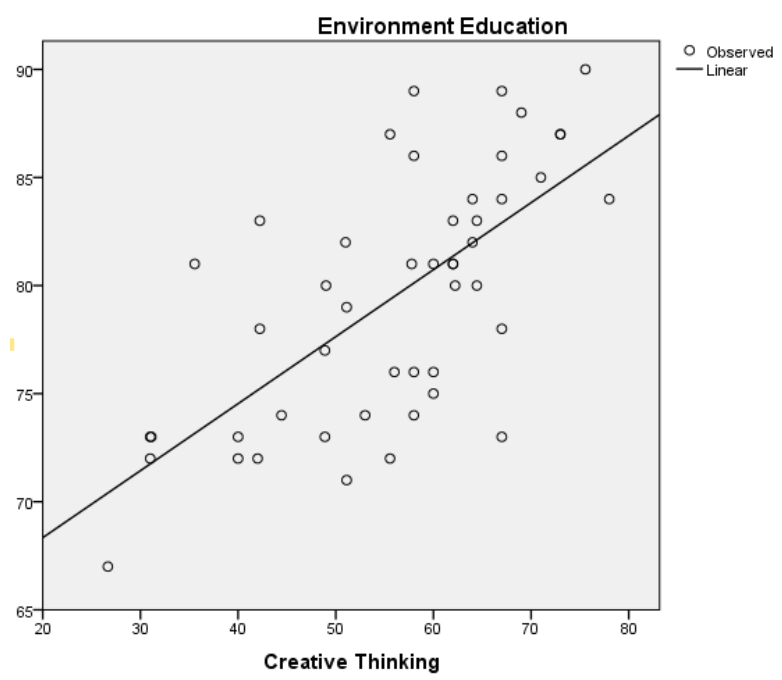

Graph 3.Students' creative thinking in solving environmental problems with achievement variables in the Environmental Education course The

Ability to think creatively can be formed in educational institutions through habituation of tasks that require students to be creative in the learning process, for example how students are accustomed to solving contextual problems in their surroundings by developing values conservation value. According to Ridlo [19], the development of conservation character in student learning activities is carried out through 
student-centered learning. They are invited to learn contextually and become imaginative, analytical, common sense, and dynamic thinker. Creativity is needed to get ideas in choosing the best solution. Therefore we need the ability to solve problems creatively. According to Lim, et al [22] CPS is understood as a structured methodology for enhancing the creative thinking of the individuals and teams. According to Isaken [21] Creative problem solving is not just problem solving, the creative aspect in it focuses on how to face new challenges as opportunities., also unknown situation. The ability of students through their experiences to apply concepts and principles, as well as theory in the learning process is expected to stimulate their creative thinking skills. Information that students have received in learning activities can be understood through the experience of the learning process. So that students who have high creativity are expected to have the ability to master concepts and principles well and are related to students' ability to solve problems creatively. According to Davies et al. [22], the impact of the creative environment on students achievement and the professional development of teachers 'creative skills', recognizing that such skills have both cognitive and practical elements. Munandar [23] defines the meaning of creativity using the four P's approach, including personal, process, product, and driving approaches. Process definition, describes the process carried out by a person with the ability to think creatively, including understanding problems, difficulties, differences in information about something, missing pieces of information, or some things that become questions so that they are able to make presumptions or hypotheses related to newfound. The presumptions that have been made are then evaluated and the results obtained are communicated.

Environmental education as a subject in the biology education study program is expected to be able to educate students to be responsive to the pace of technological development, understand ongoing environmental problems, have sensitivity to environmental problems and have the skills to carry out conservation activities. According to the North American Association for Environmental Education as quoted by Thompson and Hoffman [24], states that environmental education is learning centered; giving students the opportunity to build their own understanding by hand, thinking on inquiry in handson experience and challenges them to use higher-order thinking skills to support the development of active learning communities where students share ideas and expertise.

\section{CONCLUSION}

The results of the study indicate a significant relationship between students' creative thinking skills in solving environmental problems with the achievement of the Environmental Education subject in Uhamka biology education program students. The strong relationship between the two variables is indicated by the magnitude of the correlation coefficient value of 0.674 . The resulting determinant coefficient value is $45.5 \%$ as the amount of the contribution of students' creative thinking ability in solving environmental problems to the achievement of Environmental Education courses. The results of this study also show that the higher the students' creative thinking skills in solving environmental problems, the higher the achievement of the Environmental Education course

\section{REFFERENCES}

[1] M. Saleh, Motivation influence, family factors, campus environment and being active in organizations towards academic achievement. Phenomenon Journal, Volume 4 Number 2, 2014

[2] S. Muhibbin, Educational Psychology, Bandung: PT Remaja Rosdakarya, 2010

[3] G. Heilmann, WB.Korte, The role of creativity and innovation in school curricula in the EU27. Seville: European Commission - Joint Research Center Institute for Prospective Technological Studies, 2010

[4] L. Newton, L, S. Beverton. Pre-service teachers' conceptions of creativity in elementary school English. Thiking Skills and Creativity, 7 (3), 165-176, 2012

[5] Karwowski, Gralewski, \& Szumski, Teachers' Effect on Students' Creative Self-beliefs is Moderated by Students' Gender. Learning and Individual Differences, 44, 2015

[6] L.K.Wardani, Creative Critical Thinking (An Educational Model in the Field of Interior Design), (http // puslit.petra.ac.id / journal.interior), 2003

[7] I. Gunawan, SE Suraya, D. Tryanasari, The Relationship between Creative and Critical Thinking Ability and Student Achievement in the Science Concept II Course Peodi PGSD IKIP PGRI Madiun, Premiere Educandum, Volume 4 Number 1, 10-40, 2014

[8] B. Silaban, The relationship between Mastery of Physics Concepts and Creativity with the Ability to Solve Problems on the Subject of Static Electricity . Journal of Educational Research. Volume 20 (1): 65 - 75, ISSN 0852 0151, 2014

[9] Fatmawati et al, Critical Thinking, Creative Thinking, and Learning Achievement, J. Phys . Conf. Ser. 1417 012070, 2019

[10] Intergovernmental Conference on Environmental Education organlied by Unesco in co-operation with UNEP Tbilisi (USSR) 74 $26 \quad$ October

1977 , 
https://unesdoc.unesco.org/ark:/48223/pf00000 32763, 1977

[11] N. Purwanto, Principles and Techniques of Teaching Evaluation. Bandung: Youth Rosdakarya, 2013

[12] S.Hadi, Regression Analysis. Andi Offset Yogyakarta, 2004

[13] U.Munandar, Talented Child Creativity Development. Jakarta: Rineka Cipta, 2009

[15] S.Amtiningsih, S.Dwiastuti, D.P.Sari, Increasing Creative Thinking Ability Through the Application of Guided Inquiry combined with Brainstorming on Water Pollution Material, Proceeding Biology Education Conference (ISSN: 2528-5742), Vol 13 (1 ) 2016: 868-872 868 Biology, Science, Environment, and Learning SP-007-002, 2016

[16] C.Semiaean, Fostering Talent and Creativity of Middle School Students. Jakarta: Gramedia, 1990

[17] Anderson, L.W. Krathwohl, D.R, Airasian, P.W Cruikshank, K.A. Mayer, R.E,.Pintrich, PR, et al, A Taxonomy for Learning, Teaching, and Assissing: A Revision of Bloom's Taxonomy of Educational Objectives. New York: Longman, 2001

[18] Hungerford, HR. T. Volk, J.M.Ramsey, R.A. Litherland, and R.B Peyton, Investigating and Valuating Environmental Issues and Actions. Champaign, IL: Stipes Publishing, LLC, 2003
[19] J.SRidlo, A. Irsadi, Learning-Based Conservation Character Value Development. Journal of Educational Research Vol. 29 Number 2, 2012

[20] C. Lim, K.Park, M.Hong, An Instructional Model with an Online Support System for Creative Problem Solving, International Journal for Educational Media and Technology, Vol. 4, No.1, pp4-12, 2010

[21] S.G. Isaksen, Facilitating Creative Problem solving Groups. Published in SS Gryskiewicz \& DAHills (Eds.) Readings in Innovation, 1992

[22] D. Davies, D.J.Snape, C. Collier, R.Digbya, P. Haya, A.Howea, The impact of Creative Learning Environments on Learners: A systematic literature review. Proving Schools $16 \quad$ (1): 21-31. https://www.researchgate.net/publication/2581 41248_The_impact_of_creative_learning_envir onments_on_learners_A_systematic_literature_ review. 2013

[23] U.Munandar, Creativity and Talent Strategies to Realize Creative Potentials and talents. Jakarta: PT Gramedia Pustaka utama, 2002

[24] G. Tomson, J. Hoffman, Measuring the Success of Environmental Education Programs. Calgary, AB: Canadian Parks and Wilderness Society, 2003 